\title{
Recent development and perspectives of virtual slides (VS) and telepathology in Europe
}

\author{
Klaus Kayser ${ }^{1 *}$, Stephan Borkenfeld ${ }^{2}$, Gian Kayser ${ }^{3}$ \\ From 11th European Congress on Telepathology and 5th International Congress on Virtual Microscopy \\ Venice, Italy. 6-9 June 2012
}

\section{Background}

The new telepathology and virtual slide (VS) technology undergo remarkable changes in development and implementation. What are the reasons? What do we have to expect in the near future?

\section{Present stage}

Telepathology started in Europe in the 1980s. It was implemented in closed communication systems and focussed on frozen section service $[1,2]$. Open systems embedded in open source software replaced the early communication about 10 years ago. They became to age, and nearly all of them closed [3]. A new era started with the medical electronic communication expert system (MECES, http://www.diagnomx.eu) and the Virtual International Pathology Institute (VIPI,http://www.diagnomx. eu/vipi) that combine an internal communication network with external information nodes. It uses acoustic and visual information transfer as well as information sources at different levels such as access to libraries, image content information analysis, and diagnosis assistants [3]. It also incorporates VS, which are available from different companies. Although delivered in noncongruent formats certain medical platforms (MECES) and open access scientific journals (journal of diagnostic pathology (http://www.diagnosticpathology.org)) can handle VS via their specific viewers. VS implementation in routine tissue - based diagnosis is on its way. Most companies try to specifically connect their VS scanners to laboratory information systems (LIS) and / or to digital radiology imaging systems (picture archiving and communication system (PACS)) $[4,5]$. VS are provided with their own specific image analyzing system that focuses on evaluation of suitable immunohistochemistry scores such as Her2_neu or hormone receptors in breast cancer. Obligatory VS standards are still missing [6,7].

\section{Expectations}

The establishment of a mandatory VS standard related to PACS is on its way [8]. Recent development of so - called social forums (facebook, linkedin, youtube, etc.) has lead to new communication standards that permit the extension of open access and open software forums to external nodes. They can be considered as a communication system with internal structures \{discussion groups, communication pathways (images, sounds, movies, functions), language, data sets, etc.\} equipped with flexible communicative surface \{interpretation, measurements, quality assurance, standardization, language translation, and others\}. These information transfers can be switched on and off [9].

There are two different ways to incorporate VS in routine tissue - based diagnosis, namely (a) direct implementation of VS scanners in the existing LIS with specific connection to the hospital information system (HIS), and (b) to create an open communication network that provides as flexible communication surface to HIS, LIS, VS, etc. Industry seems to prefer method (a) although method (b) offers great advantages [10].

\section{Conclusion}

Europe is involved in big changes that involve the world of tissue - based diagnosis [11]. Surgical pathology starts to gain in clinical significance and financial interest. It is promoted by predictive diagnosis and communicative approaches which have their roots in telemedicine and digitized images [12]. The digitalization of surgical pathology has irreversibly started with big investment; the out come of the footrace is promising; however, it remains still open.

* Correspondence: Klaus.kayser@charite.de

${ }^{1}$ UICC-TPCC, Institute of Pathology, Charite, Berlin, Germany

Full list of author information is available at the end of the article

(c) 2013 Kayser et al; licensee BioMed Central Ltd. This is an Open Access article distributed under the terms of the Creative Commons Attribution License (http://creativecommons.org/licenses/by/2.0), which permits unrestricted use, distribution, and reproduction in any medium, provided the original work is properly cited. 


\section{Authors' details}

${ }^{1}$ UICC-TPCC, Institute of Pathology, Charite, Berlin, Germany. ${ }^{2}$ International Academy of Telepathology (IAT), Heidelberg, Germany. ${ }^{3}$ Institute of Pathology, University of Freiburg, Freiburg, Germany.

Published: 30 September 2013

\section{References}

1. Kayser K, Szymas J, Weinstein RS: Telepathology: Telecommunication, Electronic Education and Publication in Pathology. Berlin, Heidelberg, New Yorck: Springer; 1999.

2. Kayser K, Molnar B, Weinstein RS: Virtual Microscopy - Fundamentals Applications - Perspectives of Electronic Tissue - based Diagnosis. VSV Interdisciplinary Medical Publishing; 2006.

3. Kayser K, Borkenfeld S, Djenouni A, Kayser G: History and structures of telecommunication in pathology, focusing on open access platforms. DiagnPathol 2011, 6:110.

4. Weinstein RS, et al: Overview of telepathology, virtual microscopy, and whole slide imaging: prospects for the future. Hum Pathol 2009, 40(8):1057-69.

5. Laurinavicius $A$, et al: Digital image analysis in pathology: benefits and obligation. Anal Cell Pathol (Amst) 2012, 35(2):75-8.

6. Rojo MG, Castro AM, Goncalves L: COST Action "EuroTelepath": digital pathology integration in electronic health record, including primary care centres. DiagnPathol 2011, 6(Suppl 1):S6.

7. Rojo MG, Daniel C, Schrader T: Standardization efforts of digital pathology in Europe. Anal Cell Pathol (Amst) 2012, 35(1):19-23.

8. Jara-Lazaro AR, et al: Digital pathology: exploring its applications in diagnostic surgical pathology practice. Pathology 2010, 42(6):512-8.

9. Kayser $\mathrm{K}$, et al: E-education in pathology including certification of einstitutions. Diagn Pathol 2011, 6(Suppl 1):S11.

10. Kelly DF: Veterinary pathology in the United Kingdom: past, present, and future. J Vet Med Educ 2007, 34(4):383-9.

11. Kayser K: Introduction of virtual microscopy in routine surgical pathology - a hypothesis and personal view from Europe. Diagn Pathol 2012, $7(1): 48$.

12. Della Mea V: 25 years of telepathology research: a bibliometric analysis. Diagn Pathol 2011, 6(Suppl 1):S26.

doi:10.1186/1746-1596-8-S1-S2

Cite this article as: Kayser et al:: Recent development and perspectives of virtual slides (VS) and telepathology in Europe. Diagnostic Pathology 2013 8(Suppl 1):S2.

\section{Submit your next manuscript to BioMed Central and take full advantage of:}

- Convenient online submission

- Thorough peer review

- No space constraints or color figure charges

- Immediate publication on acceptance

- Inclusion in PubMed, CAS, Scopus and Google Scholar

- Research which is freely available for redistribution 